\title{
Sekonder Başağrılarının Acil Servise Başvuru Zamanıyla illişkisi
}

\section{The relationship between secondary headaches and admission time to the emergency department}

\author{
Elnare Günal ${ }^{1}$, Gülsen Cıgsar ${ }^{1}$, Hatice Köse Özlece ${ }^{2}$, Nergiz Hüseyinoglư ${ }^{2}$, Sergülen Aydın ${ }^{3}$ \\ 1 Kafkas University, Faculty of Medicine, Department of Emergency Medicine, Kars, Turkey \\ 2 Kafkas University, Faculty of Medicine, Department of Neurology Medicine, Kars, Turkey. \\ 3 Kafkas University, Faculty of Medicine, Department of Family Medicine, Kars, Turkey
}

öz

Amaç: Baş ağrısı acil servislerde görülen en sık şikayetlerdendir. Birincil baş ağrılarına semptomatik yaklaşım gereklidir. Ancak, hayat tehdit eden ikincil baş ağrılarını en kısa zamanda tanımlamak gereklidir. Çalışmamızda, acil servise başvuru zamanı ile ikincil baş ağrıları arasındaki ilişkiyi araştırmayı amaçladık. Çalışmanın amacı, başvuru zamanının erken tanı için ipucu verip vermeyeceğini belirlemek.

Materyal ve metot: 1350 hastanın dosyası retrospektif olarak incelendi. Çalışmaya dahil etme kriterlerine göre 711 hasta çalışmaya alındı ve iki gruba ayrıldı. Uluslararası Baş ağrısı Derneğ 2004 kriterlerine göre birincil baş ağrısı tanısı alanlar Grup A içerisine, ikincil baş ağrısı tanısı alanlar Grup B içerisine alındı. 08:00 ile 18:00 arasında baş ağrısı şikayetiyle başvuran hastalar Alt grup 1 içerisine, 18:00 ile 08:00 arasında başvuran hastalar Alt grup 2 içerisine alındı. Çalışmanın amacı, ikincil baş ağrıları ile başvuru zamanı arasındaki ilişkiyi incelemektir.

Bulgular: Yaş, cinsiyet ve başvuru zamanına ilişkin yapılan araştırmada, hiçbir parametre baş ağrısı tipini etkileyen bağımsız faktör olarak değerlendirilmedi (sırasıyla p:0.078, p:0.705 ve $\mathrm{p}: 0.547)$

Sonuç: Acil servise baş ağrısıyla başvuran hastaların başvuru zamanı tanı koyma açııından anlamlı bulunmadı.

Anahtar Kelimeler: acil, baş ağrısı

\section{ABSTRACT}

Background: Headache is one of the most common problems in emergency services. A symptomatic approach is sufficient for dealing with primary headaches. However, it is vital to identify lifethreatening secondary headaches as soon as possible. Our study aimed to investigate the relationship between secondary headaches and the time of admission to the emergency department. The study's objective was to determine whether clues for early diagnosis could be spotted at the time of admission.

Materials and methods: The files of 1,350 patients were investigated retrospectively. According to the inclusion criteria, 711 patients were included in the study and divided into two groups. Those with primary headache diagnoses according to the 2004 criteria of the International Headache Society were included in Group $A$, while those with secondary headache diagnoses were included in Group B. Patients who contacted emergency services between 08:00 and 18:00 complaining of headache were placed in subgroup 1 , while those who made contact between 18:00 and 08:00 were placed in subgroup 2 . The aim of the study was to investigate the relationship between secondary headaches and the time of admission.

Results: No parameter acted as an independent factor in affecting headache type based on research regarding the common effect of age, gender, and time of admission ( $p: 0.078, p: 0.705$, and $\mathrm{p}: 0.547$, respectively).

Conclusion: The time that patients contacted emergency services complaining of headache was not significant.

Keywords: emergency, headache

Corresponding Author: ELNARE GÜNAL

Address: Kafkas University, Faculty of Medicine, Department of Emergency

Medicine, Kars, Turkey 


\section{INTRODUCTION}

Headache (HA) is one of the problems frequently encountered in emergency services, and it accounts for $1 \%$ to $4 \%$ of all patients who contact emergency services. HA can bedivided into two groups: primary and secondary. Primary HA includes tension headaches, migraine, cluster headaches and other types not related to structural disorders. The causes of secondary HA include head trauma, intracranial masses, vascular and extravascular diseases, substance abuse, metabolic disorders, cranial neuralgia, head and neck diseases, and non-cranial infections (1). These have high mortality and morbidity in the case of missed or late diagnosis.

A generally symptomatic approach is sufficient for those who contact emergency services with primary headache triggered by routine daily activities such as head movements and walking, stress, hunger, bad working and sitting postures, and exhaustion.

However, with regard to secondary headaches, it is vital for life-threatening causes to be ruled out as soon as possible after the patient makes contact with emergency services.

The brain paranchyme is desensitized to pain, and pain originates from large brain vessels, proximal intracranial vessels and the dura mater. Life-threatening secondary HA is linked to increased intracranial pressure syndrome (ICPS) as a result of brain blood flow associated with disruption of cerebral autoregulation or an increased volume of cerebrospinal fluid. It is thought that due to the rise in $\mathrm{CO} 2$ levels in the blood during sleep, blood flow increases as a result of vasodilatation (2). Thus, headaches that are associated with intracranial pressure syndrome can occur at the nighttime. During the day, there are diurnal variations in blood pressure. This remains high from 06:00-12:00 and late morning. It is known that stroke risk is elevated during this time, and stroke is a common cause of secondary headache (3).

During rapid eye movement (REM) sleep, the cardiovascular system is unstable and sympathetic cardiac modulation is stronger $(2,4)$. Indeed, REM sleep could precipitate numerous adverse cardiovascular events such as arrhythmia, acute myocardial infarction, stroke and sudden cardiac death (5-7). For these reasons, the number of people who contact emergency services may be higher during the night because HA is caused by ICPS and stroke (2-8). Thus, our study investigated the relationship between secondary headaches and the time that patients contacted emergency services to complain of headache to determine whether the time of contact can assist in the identification of clues for early diagnosis.

\section{MATERIALS AND METHODS:}

The files of 1,350 patients who contacted the emergency department complaining of HA between 01.12.2012 and 01.12.2013 were investigated retrospectively. According to the inclusion criteria, seven hundred and eleven (711) of these patients were included in the study. The study was approved by the hospital ethics committee and is in compliance with Declaration of Helsinki.

The patients were divided into two groups. Those with a primary HA diagnoses according to the 2004 criteria of the International Headache Society (IHS) (1) were included in Group $A$, and those with a secondary HA diagnoses were included in Group B.

Patients with life-threatening vascular conditions, subarachnoid and intraparenchymal hemorrhage, and ischemic stroke symptoms were included in the secondary HA group.

Patients were excluded from the study based on the following factors: below 18 years of age; head trauma or unconsciousness; failure to cooperate with the examination; failure to provide anamnesis; substance addiction or medication intoxication; and upper respiratory tract infections such as sinusitis. Subgroup 1 comprised patients who contacted emergency services between 08:00 and 18:00 complaining of a headache. Subgroup 2 comprised patients who made contact with emergency services between 18:00 and 08:00.

\section{Statistical Analysis}

Data analysis was completed using the SPSS for Windows 22 (Chicago, IL, USA) packet program. The Kolmogorov-Smirnov test was 
used to determine whether the distribution of continuous variables was close to normal. Descriptive statistics of continuous variables were given as mean \pm standard deviation or median (minimum-maximum), while categorical variables were given as a case number and percentage. The significance between group means was investigated using student's $t$ test, while the significance of differences between median values was investigated using the Mann Whitney $U$ test. Categorical variables were assessed using the Pearson's chi-square or Fisher's exact test. Logistic regression analysis was performed to assess the common effect of independent factors. A value of $p<0.05$ was defined as statistically significant.

\section{RESULTS}

Screening was carried out on the patient files of 1350 patients who contacted emergency services complaining of HA on consecutive days over one year. According to the inclusion criteria, seven hundred and eleven (711) of these patients were included in the study. The average age of the patients was 39 years (18-84) with a female/male ratio of 1.24. While 696 patients (97.9\%) were found to have primary HA (Group A), 15 patients $(2.1 \%)$ were found to have secondary HA (Group B).

Of the 696 patients included in Group A, $380(54.5 \%)$ had tension headache, 250 (35.9\%) had migraine, and 66 (9.4\%) had cluster headaches. Of the patients included in Group B, 13 (86.6\%) had stroke, one (6.6\%) had an intracranial mass, and one (6.6\%) had a subarachnoid hemorrhage. These are known conditions that can lead to the development of a secondary headache.

The average age in Group A was 41.3 \pm 19.6 , and the female/male ratio was $386 / 310$. In Group B, the average age was $52.8 \pm 18.5$ (p:0.012), and the female/male ratio was $7 / 8$ (Table 1) (Figure 1). The average age of Group $B$ patients was much higher than the average age of Group A patients ( $p: 0.012$ ). While 434 of the 711 patients (61\%) contacted emergency services between 08:00and 18:00 (Subgroup 1), 277 patients (39\%) made contact between 18:00 and 08:00(Subgroup 2)
(Figure 2). Of the 696 patients in Group A, 423 made contact between 08:00 and 18:00 (Subgroup 1), and 273 made contact between 18:00 and 08:00 (subgroup 2). In Group B, 10 of the 15 patients contacted emergency services between 08:00 and 18:00 (Subgroup $1)$, and 5 patients made contact between 18:00and 08:00 (Subgroup 2) (Table 2). When the patients were compared in terms of the time they contacted the hospital, there was no statistically significant difference between patients with primary and secondary HA (p:0.644).

No parameter acted as an independent factor in affecting headache type based on research regarding the common effect of age, gender, and time of contact with the hospital ( $p: 0.078, p: 0.705$, and p:0.547, respectively).

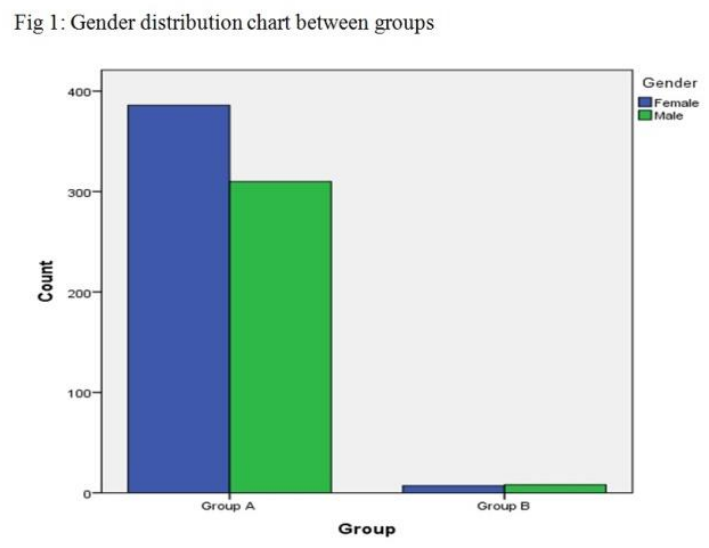

Fig2: Admission time distribution chart between groups

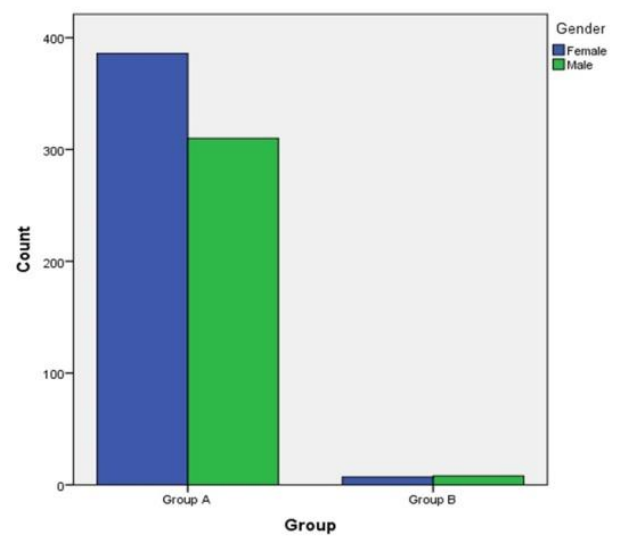

\section{DISCUSSION}

Headaches are divided into primary and secondary types. In the general population, secondary HA accounts for $10 \%$ of all headaches $(2,9)$. It is very important that the character of the HA be determined from clues in anamnesis and physical examination 
because rapid and correct diagnosis is vital if life-threatening secondary HA is suspected.

Table 1: Demographic characteristics of the patients.

\begin{tabular}{|c|c|c|c|c|}
\hline Characteristics & $\begin{array}{c}\text { Patient } \\
\text { number/rate }\end{array}$ & Group A & Group B & Pvalue \\
\hline Age (years) & $39(18-84)$ & $41.3+-19.6$ & $52.8+-18.5$ & $\mathrm{p}: 0.012$ \\
\hline $\begin{array}{c}\text { Gender } \\
\text { (female/male) }\end{array}$ & 1.24 & $386 / 310$ & $7 / 8$ & $\mathrm{p}: 0.012$ \\
\hline
\end{tabular}

Table 2: Statistical analysis of relationship between groups and subgroups.

\begin{tabular}{|c|c|c|c|}
\hline & Number & $\begin{array}{l}\text { Time of contact } \\
\text { 08:00-18:00 } \\
\text { (Subgrup 1) }\end{array}$ & $\begin{array}{l}\text { Time of contact } \\
\text { 18:00-08:00 } \\
\text { (Subgrup 2) }\end{array}$ \\
\hline Group A & 696 & $423(60.7 \%)$ & $273(39.2 \%)$ \\
\hline Group B & 15 & $10(66.6 \%)$ & $5(33.3 \%)$ \\
\hline
\end{tabular}

Age is an important factor in stroke. It is dangerous and causes visits to the emergency department. It is known that $70 \%$ of stroke victims are over the age of 65 (10). While the prevalence of primary headaches like migraine, stress headaches, and cluster headaches reduces with age, the prevalence of secondary headaches increases $(11,12)$. A study by Çığşar et al. (12) found that the average age of stroke patients was over 61 years. In our study, the average age of patients in Group B was higher than in Group A. As a result, it is important that elderly patients who contact emergency services complaining of HA be evaluated carefully from a neurological standpoint because the HA may relate to a neurological problem (13).

Many studies (14-16) note that stroke is observed slightly more often in men of all age groups. While a study by Efstathiou et al. stated that the percentage of male patients in the hemorrhagic group was $51.2 \%$ (17), a study by Mc Call et al. stated that $52.6 \%$ of the stroke patients were female (18). In our study, the rate of females to males in Group B was $7 / 8$.

Some studies report that the majority of stroke patients who are found to have secondary headaches contact the hospital during evening and night. Kiyan et al. studied 124 stroke patients and observed that $60.5 \%$ of them contacted emergency services during the night (18:00-08:00) (19). This may be due to an increase in $\mathrm{CO} 2$ levels at night, which leads to vasodilatation and causes a secondary headache to develop. It may also be due to unstable sympathetic activity in REM sleep in the early morning. This explains the coincidental increased cardiovascular risk (28). On the contrary, another study showed that the blood viscosity reaches its highest value in the morning hours, and the incidence of stroke increases around noon relative to the early morning hours. Endogenous tissue plasminogen activator that regulates the balance between thrombosis and fibrinolysis activity has been shown to be at a minimum in the morning. That could explain the increase in thrombosis and stroke incidence in the morning.

However, in our study, we found no significant difference between primary and secondary HA patients in terms of the time they made contact with emergency services (p:0.064). We found that $66.6 \%$ of Group B patients arrived during the day shift 108:0018:00). There was no statistical difference found between the arrival times of those with primary and those with secondary headaches.

Our study shows that the time contact is made with the hospital is not a warning factor and cannot be used to distinguish primary and secondary HA. Rather than emphasizing the time of initial contact with emergency services, the time that the initial symptoms are evaluated should be carefully assessed and the importance of correct and rapid diagnosis should be remembered.

\section{Limitations}

The most important limiting factor of our study is that we could not include all of the patients admitted in 1 year period due to missing files. Also we could not get any information about begining time of headache because both our study is retrospective and anamneses written on patient files not complete

\section{CONCLUSION}

The time the patients made contact with emergency services complaining of HA was not significant. In fact, the time that the initial complaint is evaluated in hospital is more important because patients' arrival at the hospital may often be delayed due to their 
living conditions and other socioeconomic factors. As a result, when it comes to patient assessment, the main focus should be on the time of the initial assessment at the hospital rather than when contact was first established with emergency services.

Conflict of Interest: The authors declared no conflict of interest.

Financial Disclosure: The authors declared that this study has received no financial support.

\section{REFERENCES}

1. Headache classification subcommitee of the International Headache Society. The International Classification of Headache Disorders, 2nd ed. Cephalgia 2004;24:1-160.

2. Cabiddu R, Cerutti S, Viardot G, Werner S, Bianchi AM. Modulation of the sympatho-vagal balance during sleep: Frequency domain study of heart rate variability and respiration. Front Physiol 2012;3:45.

3. James GD, Toledano T, Datz G, Picgering TG. Factors influencing the awake-sleep difference in ambulatory blood pressure: main effects and sex differences. J Hum Hypertens 1995; 9:821-826.

4. Somers VK, Dyken ME, Mark AL. Sympathetic-nerve activity during sleep in normal subjects. N Engl J Med 1993;328:303-7.

5. Portaluppi $\mathrm{F}$, Tiseo $\mathrm{R}$, Smolensky $\mathrm{MH}$, Hermida RC, Ayala DE, Fabbian F. Circadian rhythms and cardiovascular health. J Sleep Med Rev 2012;16:151-66.

6. Lavery $C E$, Mittleman MA, Cohen MC, Muller JE, Verrier RL. Non uniform nighttime distribution of acute cardiac events: A possible effect of sleep states. J Circulation 1997;96:3321-7.

7. Holty JE, Guilleminault C. REM-related bradyarrhythmia syndrome. J Sleep Med Rev 2011;15:143-51.
8. Tindall GT, Cooper PR, Barrow DL: The Practice of Neurosurgery 1997, Williams\&Wilkins.

9. Oguzhan Ç. Serebrovaskuler olayların sımıflandırılması, epidemiyolojisive risk faktörleri. Neurology. İstanbul. Nobel Medicine Bookstore 2004;193-4.

10. Fowler MV, Capobianco DJ, Dodick DW. Headache in the elderly. Seminars in PainMedicine 2004;2:123-128.

11. Martins KM, Bordini CA, Bigal ME, Speciali JG. Migraine in the elderly: A comparison with migraine in young adults. J Headache 2006;46:312316.

12. Çıgsar G, User NN. Acil Servise Başvuran Akut Inmeli Hastaların Analizi. J Kafkas Med Sci 2015;5(1):6-12.

13. Tanganelli P. Secondary headaches in the elderly. J Neurol SCi 2010;31:73-76.

14. Hakbilir O, Cete Y, Goksu E, Akyol C, Kılıçaslan i. İnme populasyonun demografik özellikleri ve geç acil servis başvurularının yeni tedavi yaklaşımları üzerine etkisi. J Turkish Emerg Med 2006;6 (3):132-138.

15. Keskin O, Kalemoglu M, Deniz T. Akut inme hastalarında acil müdahileyi etkileyen faktörler. J Turkish Emerg Med 2004;4:160-164.

16. Keskin O, Kalemoglu M, UlusoyE, Uzun $\mathrm{H}$, Yıldırım i. Investigation the reasons for the delay in the pre-hospital acute stroke patients. Nobel Medicus Online journal http://www.nobelmedicus.com/contents/200511/ 14-17. htm.

17. Efstathiou SP, Tsioulos DI, Zacharos ID, Tsiakou AG, Mitromaras AG, Mastorantonakis SE, et al. A new classification tool for clinical differentiation between haemorrhagic and ischemic stroke. J InternMed 2002; 252:121-9.

18. McCall SJ, MusgraveSD, Potter JF, Hale R, Clark AB, Mamas MA, et al. The shock index predicts acute mortality outcomes in stroke. J Int Cardiol 2015;182:523-527.

19. Kıyan S, Ozsarac M, Ersel M, Aksoy E. Acil servise başvuran akut iskemik inmeli 124 hastanın geriye yönelik 1 yıllık incelenmesi. J AEM 2009;8:3. 